\title{
Gradhiva
}

GRADHIV

Revue d'anthropologie et d'histoire des arts

$7 \mid 2008$

Le possédé spectaculaire

\section{The Festive Sacred and the Fetish of Trance}

Performing the Sacred at the Essaouira Gnawa Festival

Le sacré festif et la transe fétiche. La performance du sacré au festival gnaoua et musiques du monde d'Essaouira

Deborah Kapchan

12 Journals

Electronic version

URL: http://journals.openedition.org/gradhiva/1014

DOI: 10.4000/gradhiva.1014

ISSN: $1760-849 X$

Publisher

Musée du quai Branly Jacques Chirac

Printed version

Date of publication: 15 May 2008

Number of pages: $52-67$

ISBN: 978-2-915133-86-8

ISSN: 0764-8928

Electronic reference

Deborah Kapchan, «The Festive Sacred and the Fetish of Trance », Gradhiva [Online], 7 | 2008, Online since 15 May 2011, connection on 19 April 2019. URL : http://journals.openedition.org/gradhiva/1014 ; DOI : 10.4000/gradhiva.1014 

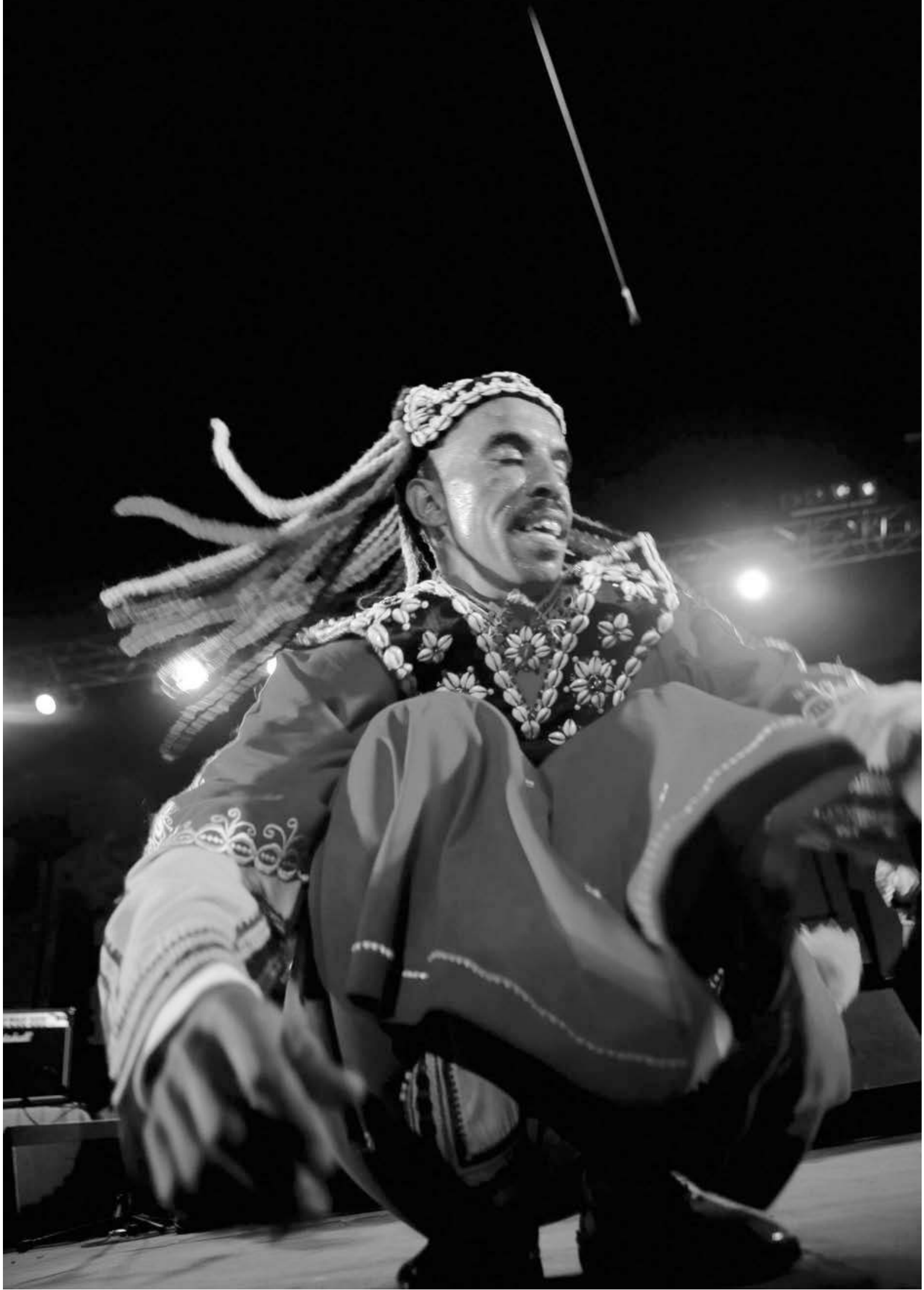

Fig. 1 Spectacle gnawa au «festival gnaoua et musiques du monde d'Essaouira », 24 juin 2006. @ Pierre-Emmanuel Rastoin (P. E. R.). 


\title{
The Festive Sacred and the Fetish of Trance
}

\author{
Performing the Sacred at the Essaouira Gnawa Festival \\ of World Music
}

I

t is late June 1999 and I am in Essaouira, Morocco, for the Essaouira Gnawa Festival of World Music.

The weather is balmy, but the wind of this coastal city blows so hard that the festival-goers clasp their scarves tightly around them. During the day I attend a conference on trance organized by ethnopsychiatrist and Gnawa scholar Abdelhafid Chlyeh. He has brought together some of the most renowned scholars of trance, and particularly of the Gnawa - Viviana Pâcques is here, Abdelghani Maghnia, Abdelhai Diouri, Vincent Crapanzano, Sheila Walker, and others. In the afternoon we attend a ritual sacrifice of a sheep intended to initiate the festival, itself conceived as a large Gnawa lila, or propitiation ceremony to the spirits. It is a public ceremony, with music and prayers. The Gnawa burn the ritual incense, singing the invocations to the Prophet and to the spirits. The sheep is sacrificed, the animal taken to another room for cleaning, and the blood on the blue and white tiles washed away. Slowly, the crowd disperses. The festival technically has now begun.

That night, I listen to Reggie Workman jam with the Gnawa at the public concert on the square. Richard Horowitz is on the bill, as are Adam Rudolph, Hassan Hakmoun, Sussan Deyhim and a group known as Gnawa Diffusion. Leaving the concert venue a bit early, I search the Essaouira streets for the Gnawa sanctuary (zawiya) where the ritual lila is being held. While more crowded than a normal lila, with more Westerners in attendance,

it still unfolds $b$-haqq-u u treq-u, in its truth and its path. In 2004 I find myself in Essaouira again. There is another conference - this time on religion and slavery organized by another scholar, historian Mohammed Ennaji. In the intervening years, several four and five star hotels have been constructed. The conference is at one of them, built a few miles outside of the city limits. We take mini-vans into town to attend the music concerts. That afternoon there are so many people in the small fishing village that, while walking through a city gate, I am lifted off my feet. But in the evening, on the grand square, the crowds have more room. We listen to Hassan Hakmoun, the ex-patriot Gnawi who now lives in New York, and the audience trances out. "La ilaha illa-llah," the Gnawa chorus chants behind Hakmoun, "there is no God but God."

There is no lila this year, at least not literally. But the term is now used very loosely, and applies to many of the musical performances on stage. It's in the festival literature, on the Web, on people's tongues. Like trance, the ritual ceremony has become a sign that has peeled away from its customary use to circulate in new contexts with new associations. This is not spurious; rather, the carnivalesque aspects of the possession ceremonies themselves - which include music, ecstatic trance, mortification rites, as well as the occasional use of cannabis (and other intoxicants) - facilitate their exportation to the international festive arena.

Gradhiva, 2008, nº 7 n.s. 
What happens when a sacred and local practice such as trance is made into a fetish, detaching itself from its context of origin and circulating in transnational markets and international music festivals as a sign that carries its own power? When a ritual practice is so appropriated, it not only affects its performance context — the social milieu of its exchange - but the practice itself is transformed. This is the case with what is often called "trance" as it travels in the global market: it is made into a fetish, treated as an object with transformative powers, ultimately becoming a form of symbolic capital that helps create the category of the "sacred" in a transnational context.

In this article, I focus on one example of such fetishization - The Essaouira Gnawa Festival of World Music in Morocco. The festival, which takes place in a Muslim country, is not religious per se, but nonetheless performs what until now has been a private and local ritual for both national and international audiences. Based on more than a decade of research with ritual Gnawa musicians in Morocco (Kapchan 2007), I demonstrate "how the blurred boundary between religion and entertainment, facilitated by forces of commercialization, offers new possibilities for the proliferation of religion" (Meyer and Moors 2006: 3). Rather than representing a resurgence of religious interest, however, I argue that the phenomenon of the sacred music festival draws on the religious sentiment evoked by ritual music in order to create a transnational (thus mobile) notion of the sacred, what I call the "festive sacred," that is in many ways a counter-point to the specificity and ideology of more orthodox forms of religious practice. It does so by enacting a promise - what I refer to as the "promise of sonic translation" - the hope that music can translate sacred affect across cultural and linguistic divides. Emphasizing the "universality" of music, and fetishizing "trance" and "Sufism," international music festivals like the one in Essaouira construct a notion of the sacred for audiences who come faithfully and regularly from great distances to "trance out" to the music.

\section{Performing Gnawa-ness, tagnawit}

The Gnawa are a sub-Saharan population that came to Morocco mostly as slaves in the 15th and 16th centuries, though some traveled over land in the caravan trade as free agents (Hell 1999, 2002; Kapchan 2007; Pâques 1991; Schuyler 1981). The late anthropologist Viviana Pâques noted that some Gnawa still remember who came by boat in bondage, and who came over the Sahara in the forced service of the Moroccan sultanate (Pâques 1991). Those who came by boat often passed through Essaouira (the former Mogador) on their journey north to eventually cross the Atlantic. This history of slavery, however, remains more or less unvoiced at the festival, while the aesthetic connections with the larger African diaspora are stressed.

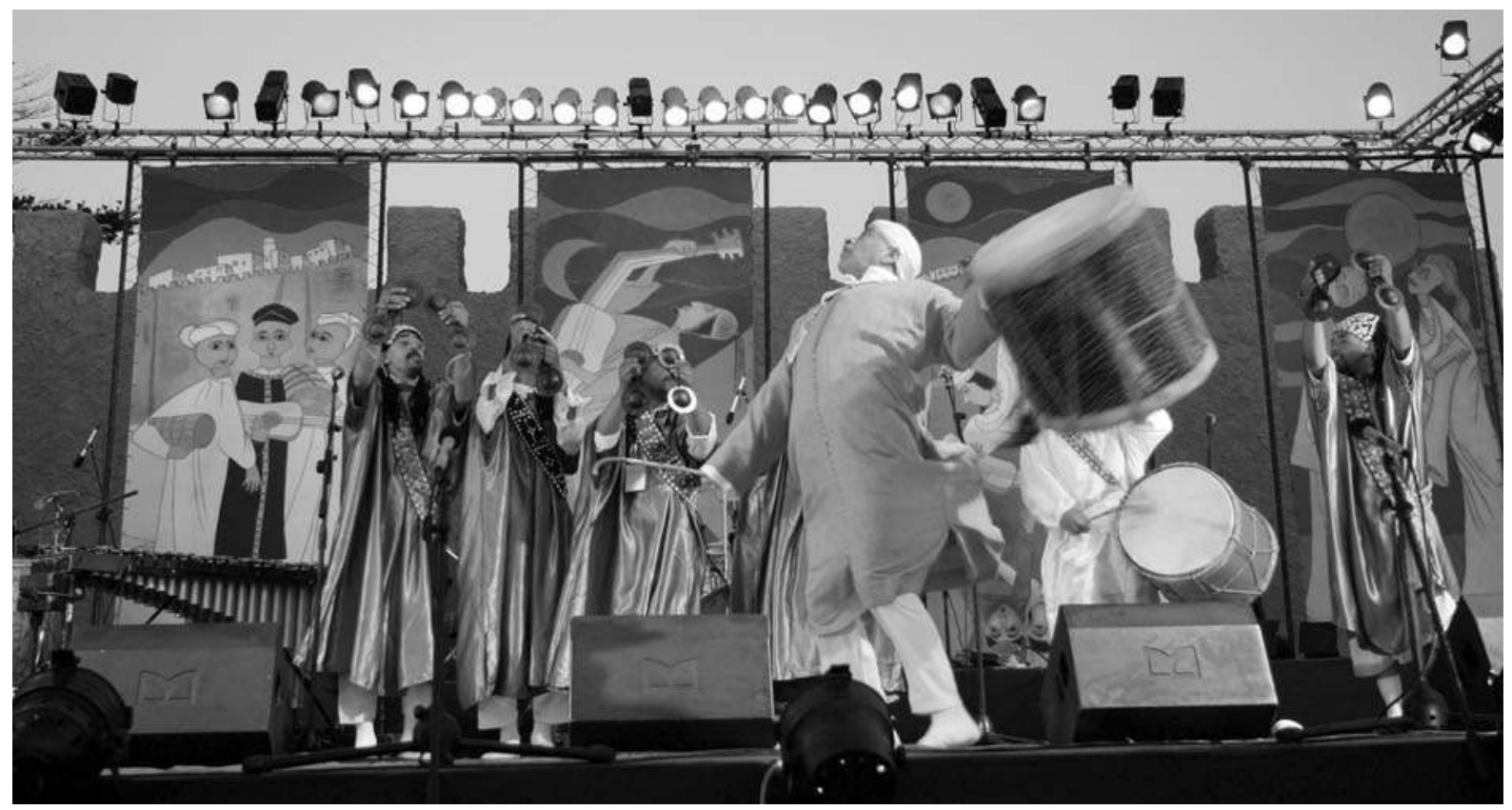

Fig. 2 Musiciens gnawa au festival, 26 juin 2004 @ P. E. R. 


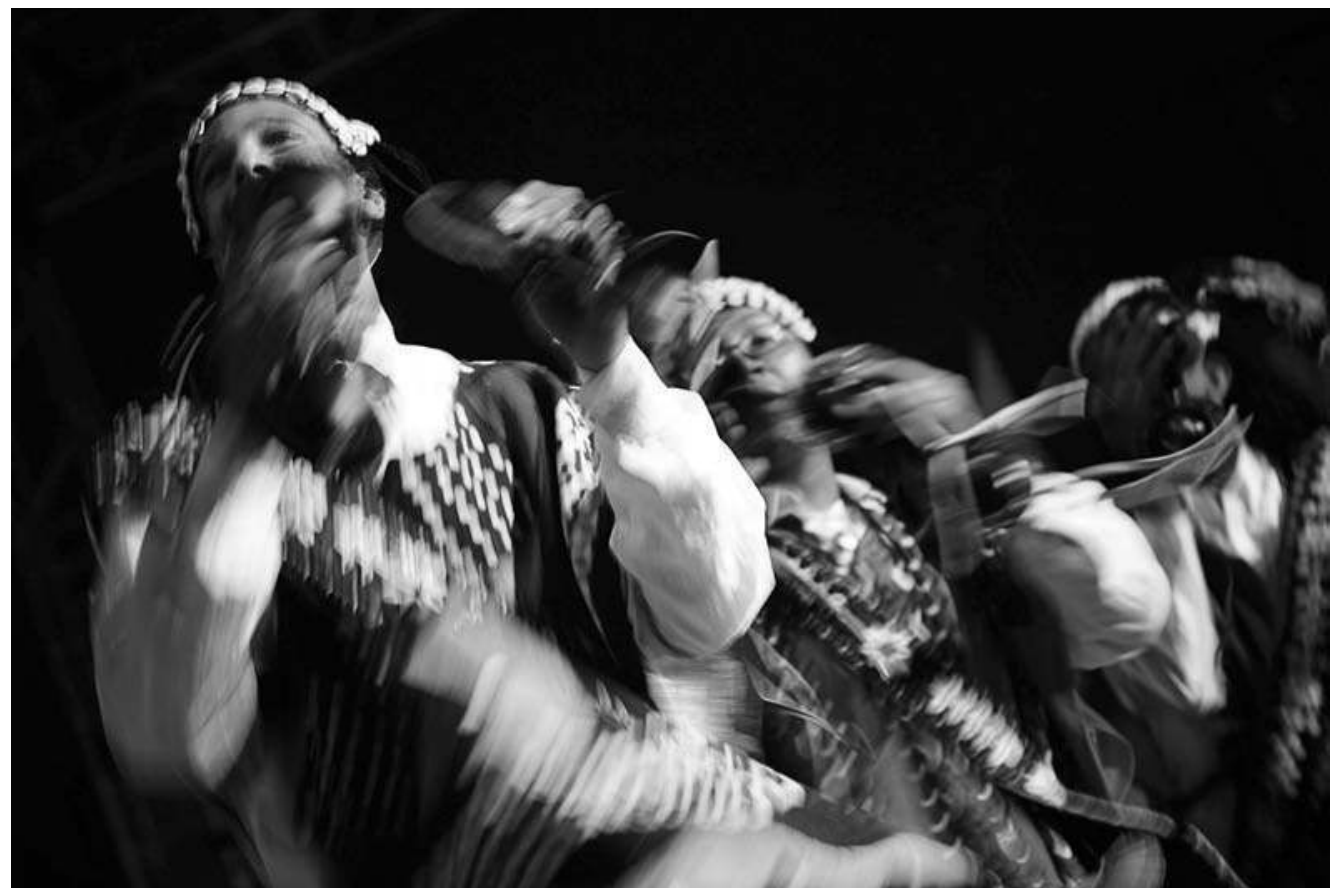

Fig. 3 Musiciens gnawa au festival, 26 juin 2006 @ P. E. R.

The Gnawa are Muslims who heal those possessed by spirits with ritual music in an all-night ceremony called a derdeba lila, or simply a lila or "night". The music is pentatonic and highly rhythmic. The Gnawa represent a syncretism between Islamic and African ritual aesthetics in the way that Candomble or Santeria combines Christian beliefs and practices with those of Voudun. Because they are Muslims who employ music in their praise, the Gnawa are often put into the category of Sufis. Although both the definition of Sufism and the relation of the Gnawa to mystical Islam can be contested, ${ }^{1}$ what is incontrovertible is that the Gnawa are marketed and usually perceived as Sufis. And in fact, like all religious expression in Morocco, the Gnawa ceremonies are impregnated with Sufi influences (Cornell 1998; Eickelman 1976).

Traditionally, Gnawa musicians have been ritual specialists, assuaging the spirits with music and incense. The primary specialist is the m'allem, the master, who plays a three-stringed lute-like instrument called the hajhuj and sings. The m'allem is accompanied by several men who often respond to the m'allem's lyrical calls, and who play heavy metal castanets called the qraqab. There is also a female overseer, called a mqademma, who intervenes between the spirit and the human realm. In the Gnawa idiom, the possessed are said to be maskun, inhabited. Spirits "rise up" in the body, and the possessed then "fall" into trance. The resulting trance, or jadba, is both a performance by the spirits in the body of the possessed, and a way to assuage the affliction that possession causes. At more advanced stages of initiation, Gnawa practitioners may "work the spirits," that is, control their interactions with the spirits rather than be their victims. In fact, trancing employs a gestural and emotional economy similar to the ecstatic states of Moroccan Sufi practitioners, who are not possessed (Kapchan 2007). These states of ravissement are frequent at ritual ceremonies (Hell 2002).

Until recently, Gnawa musicians underwent an apprenticeship, often from father to son. The title of m'allem was conferred, not appropriated, and demanded a deep and time-consuming study of both the spirit realm and music. Those who still possess this knowledge have what the Gnawa refer to as tagnawit (literally Gnawa-ness), a qualifier that denotes an advanced stage of ritual mastery. It is a way of distinguishing

1. From a historical perspective, the Gnawa may be put into the category of Sufis. From the point of view of contemporary practice, however, and according to Moroccans who self-identify as Sufis, the Gnawa are not Sufis, having neither shaykh nor hagiography (the post-facto claiming of Sidi Bilal notwithstanding). They are, nonetheless, Sufiinfluenced, a ta'ifa (a community) rather than a tariqa (Sufi path). For Hell [2002] and Pâques (1991) the Gnawa are Sufis, while for Kapchan (2007) they are not. 
"authentic" from "inauthentic" performance. Today there are many people who call themselves Gnawa who do not have tagnawit. They learn the music (often through apprenticeship) but do not learn the secrets of the spirit realm. Indeed, the disentangling of ritual knowledge from musical knowledge has been taking place since the 1960 s at least, when the Gnawa became prominent actors in the Moroccan popular music scene and were subsequently "discovered" by both American and British rock-and-roll musicians, as well as by African-American jazz musicians (Kapchan 2007). The enthusiasm of foreign musicians for this ritual and "African" music has led the Gnawa to protect their secrets, though over the span of two generations the pedagogy of apprenticeship has also changed radically. The entry of the Gnawa onto the world music scene and the accompanying commoditization of the Gnawa "sound," has both weakened the local traditions (which perform healing and social cohesion but are not very lucrative) and strengthened international recognition, aligning and codifying a musical style with a MoroccoAfrican identity in the process. Young Gnawa now have their sights set on record companies and international tours rather than on healing the possessed in their local neighborhoods. The effervescence of the local ceremonies has not disappeared, however; rather it has been transferred to the global stage. Ironically, the very musical groups whose members have no tagnawit are those for whom the discourse of spirit possession, and trance, become most salient. They have learned that "the sacred" sells.

\section{The Festive Sacred}

"We must learn to judge a society more by its sounds, by its art, and by its festivals, than by its statistics" (Attali 1985: 3).

Historically, festivals in Morocco brought people together around the celebration of a saint or religious holy day (Eickelman 1976). The sacredness of festivals was expressed in time - festivals were set apart from quotidian time, creating a "time out of time" - and space (Callois 1960; Falassi 1987: 4). Of course, large gatherings of people provided an ideal opportunity for commercial exchange, and saints festivals (or mawasim) and markets were often held at the same time and in the same place. This practice continues today in such celebrations as the moussem of Moulay Brahim in the High Atlas mountains (Hell 2001). As early as the 1950s, however, non-religious festivals like the Marrakech
Folklore Festival became popular. This festival, and others that followed, displayed the cultural diversity of Moroccan music and dance traditions to both European and Moroccan tourists. In the 2oth century, international festivals - in Morocco and elsewhere - continue to display national diversity to local audiences, but increasingly they also attract diverse audiences to exotic and often "sacred" locales. ${ }^{2}$ Moreover, it is now necessary to demarcate festivals that self-consciously construct the sacred from those that enact it under other guises; that is, some festivals are specifically marked for "the sacred" with strategic intent.

\section{The Festive Sacred, and the Nation}

In post-independence Morocco, festivals became both more international and more secular. Indeed, Morocco is now a country of festivals. While there are still religious festivals associated with a local saint, each year the Ministry of Culture sponsors more than a dozen nonreligious festivals that celebrate local traditions as much as they fete the diversity of national culture. The Festival of Andalusian Music is held in Chef Chaouen, for example, the oldest Andalusian city in Morocco. Similarly, the aita festival is held in Safi, the city most known for this genre of music (often called shikhat music). Several of these festivals celebrate the cultural and linguistic diversity of Morocco (particularly the Festival de Poésie et Chant Amazigh in Midelt and the Festival Poésie et Chant Hassani in Dakhla), thereby giving value to populations and races that have been marginalized, if not oppressed and discriminated against in the past (Guss 2000). There are also celebrations of zajal, spoken poetry in dialect, as well as symposia on Moroccan literature and visual arts. In addition to these national festivals there are several international festivals in Morocco patronized by the King and sponsored by the private sector; these include the Mouazzine ("Rhythms") Festival in Rabat, the Tangier Jazz Festival, the Fes Festival of World Sacred Music (Kapchan forthcoming) and the Essaouira Gnawa Festival of World Music.

The Moroccan monarchy has many stakes in the spate of yearly festivals. They construct a public discourse of neo-liberalism, even when the policies of the government are in contradiction of the same; they occupy the youth and intelligentsia (who are recruited in their production) and create a public culture of festivity that dif-

2. See Bauman et al. 1992; Brandes 1988; Guss 2000; Noyes 2003; see also Abrahams 1987; Turner 1982. 


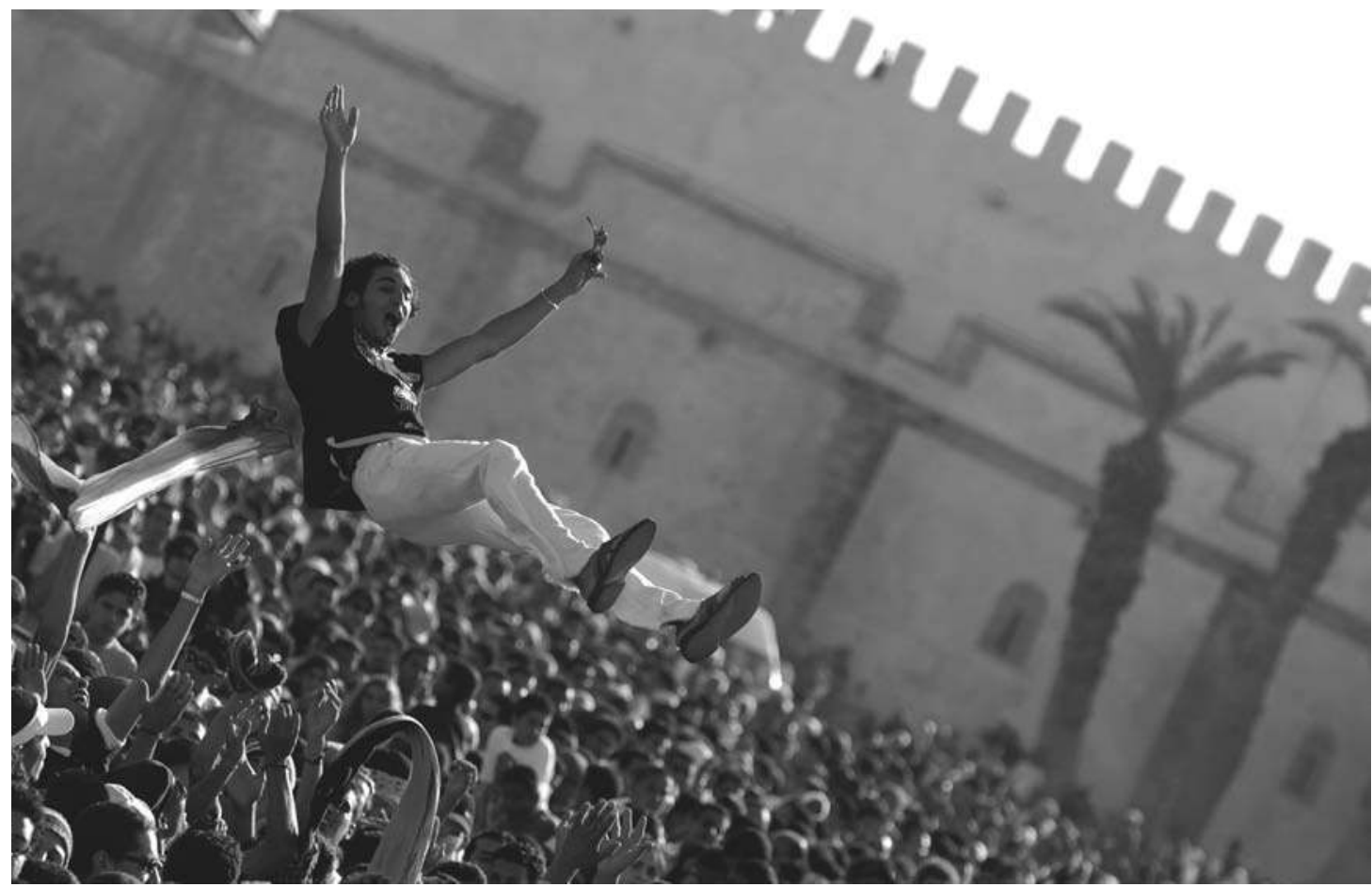

Fig. 4 Public du festival, 29 juin 2003, $6^{\text {e édition. } \odot ~ P . ~ E . ~ R . ~}$

fuses animosities in other arenas. They also engage the producers of these festivals (usually artists and academicians nominated to political positions in the Ministry of Culture) in the active creation of Moroccan culture as a product for national and international consumption, the tourism industry being one of the most profitable sources of income for the Moroccan state. In short, the nation has much to hope for in festival production, both materially and otherwise.

These festivals, however, are not without their public opponents. On June 25th of 2004, for example, the imam of the Hassan II mosque in Casablanca delivered a sermon ( $k h u t b a$ ) in which he condemned several practices in the Moroccan public sphere, among them, women's access to public beaches, mixed-sex working conditions and music festivals. This sermon, broadcast on Moroccan radio and television, exemplified a conservative backlash provoked by both the newly instituted family code laws (giving women more rights) and the fear unleashed by the Casablanca bombings a year earlier. Coming at the height of the festival season in Morocco, journalists as well as festival promoters did not fail to counter this attack in their media coverage. The Collective for Democracy and Modernity ran a fullpage response in the French-language Journal Hebdomadaire in July in which they stated that the "sermon [wa]s part of a campaign orchestrated by les intégristes [Islamists] every year at the beginning of summer, following up on articles calling for the prohibition of music, festivals and summertime gatherings." In response to the sermon, journalists wrote passionately about the socio-political benefits of festivals, particularly the Essaouira Gnawa Festival of World Music that had just begun. They touted the exuberant and diverse crowds, as well as people's ability to live and celebrate together in Essaouira, a pilgrimage center for Jews, Arabs and sub-Saharan populations.

As festivals take on lives of their own, they become a testing ground for free speech, free-market capitalism and civil liberties - the hopes, it may be said, of a modernizing nation. Yet the hand of the state is not the only agent in the production of these festivals. Despite the fact that they take place in old historic cities such as Essaouira, the festivals are in no wise "local" in their effects. Indeed, the festive sacred participates in a new order that is, in part, a response to the proliferation of sectarian and mobile movements that characterize the post-modern moment (Appadurai 2006).

Music festivals represent the anti-thesis of religious conservatism not only because they are explicitly denounced by people like the imam of the Hassan II mosque, but because the festival organizers, as well as 
the participants, self-consciously construct an alternative notion of the sacred for public and popular consumption. It is not just "the secular" that threatens the imam, at least in the case of the festival, but another way to define the sacred.

\section{The Festive Sacred, the Transnational} and the Promise of Sonic Translation

If the creation of sacred tourism works to bring income to the Moroccan tourism industry while also creating discourses that counter growing religious conservatism nationally, these effects are inseparable from the transnational sphere. Indeed, the audiences at these festivals come from Morocco, France, and the United States year after year to listen to world music from many parts of the globe. They are the festive faithful. How then do heterodox audiences become perennial communities of sacred affect?

I assert that these listeners become a community of affect (rather than of ideology) not through their religious beliefs per se, but through participation in a common promise - the promise of translation: "The event of a translation, the performance of all translations," notes Derrida in his study of Benjamin, "is not that they succeed. A translation never succeeds in the pure and absolute sense of the term. Rather, a translation succeeds in promising success, in promising reconciliation. [...] A good translation is one that enacts the performative called the promise with the result that through the translation one sees the coming shape of a possible reconciliation among languages (Derrida 1985a : 123; Benjamin 1969).

Audiences in Essaouira inhabit the promise of this "reconciliation," but the language of promise is musical; that is, what festival organizers promise - in

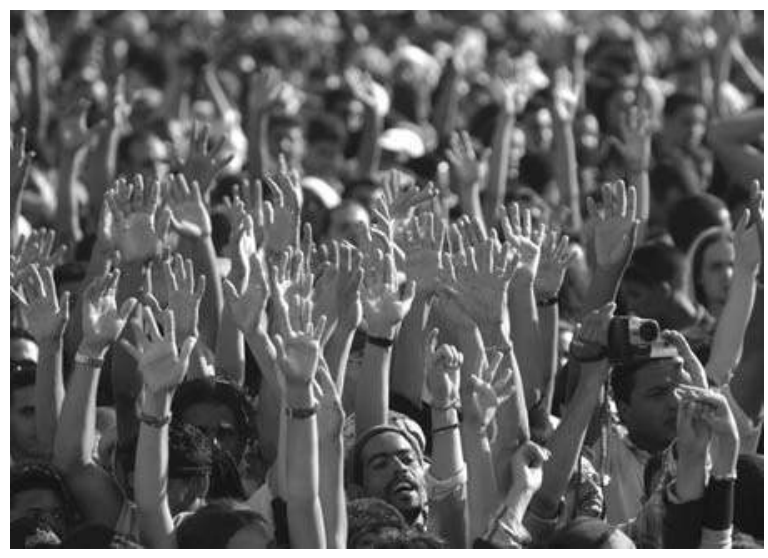

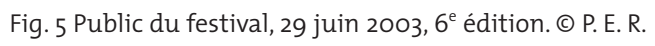

brochures, travel literature and conference discourse is sonic translation. This is not done by explicitly analyzing the aesthetic styles of different traditions, but rather by creating conditions that predispose audiences to the aural reception of difference. This process, this promise, creates an audience defined by diverse tastes but a common desire: namely, to consume the sacred in its many guises. Whether floating in the melodies of Senegalese singer Youssou N'Dour, grooving with the harmonies of Cuban pianist Omar Sosa, bobbing the head up and down in trance to the Moroccan Gnawa, or rocking out to the Wailers, the diverse auditors at the Essaouira Festival open their ears to new sounds, and their minds to new understandings of what the sacred might mean in different traditions. These include the Rai sounds of Cheb Mami, the sacred-pop fusion of Egyptian Fathy Salama, and the griotte-inspired music of Malian Naïny Diabaté. Couple these traditions with the sounds of Elika and Solo, a Swedish violinist and Senegalese kora player and singer, or the world beats of American percussionist Adam Rudolph, and a large section of Africa, Europe and the United States is represented. World beat becomes a sort of sacred recipe for peace in this festival, and multi-cultural musical expression itself becomes a sacred ritual enterprise. ${ }^{3}$

\section{The Gnawa Festival}

Since its birth in 1998, the Gnawa Festival has become increasingly popular. Not only are the concerts free and open to the public, but some of the most well-known North African, European and American musicians perform on the stage. While the music is not explicitly labeled "sacred" in Essaouira, there is definitely an effort made to capitalize on the phenomenon of trance as practiced by the Gnawa, and to create a kind of transcultural trance from the palette of musicians presented. Transcendence is a leitmotif. The case in Essaouira demonstrates that music festivals need not be labeled "sacred" in order to participate in the production of the festive sacred.

Sacred metaphors abound in the Gnawa festival: "Old hippie capital and new temple of world music, Essaouira

3. Perhaps the most renowned world music festival, the international World of Music, Arts and Dance Festival (WOMAD), for example, brings world musicians and world audiences together to celebrate multi-culturalism and promote peace. Like the Gnawa festival, the music is a represented as a "universal language." Their 'Voices of the Ancestors' series "introduces musicians whose work is steeped in a sense of social and spiritual history, exploring the places where their cultural heritage converges and diverges" (http://womad.org, accessed December 2007). 


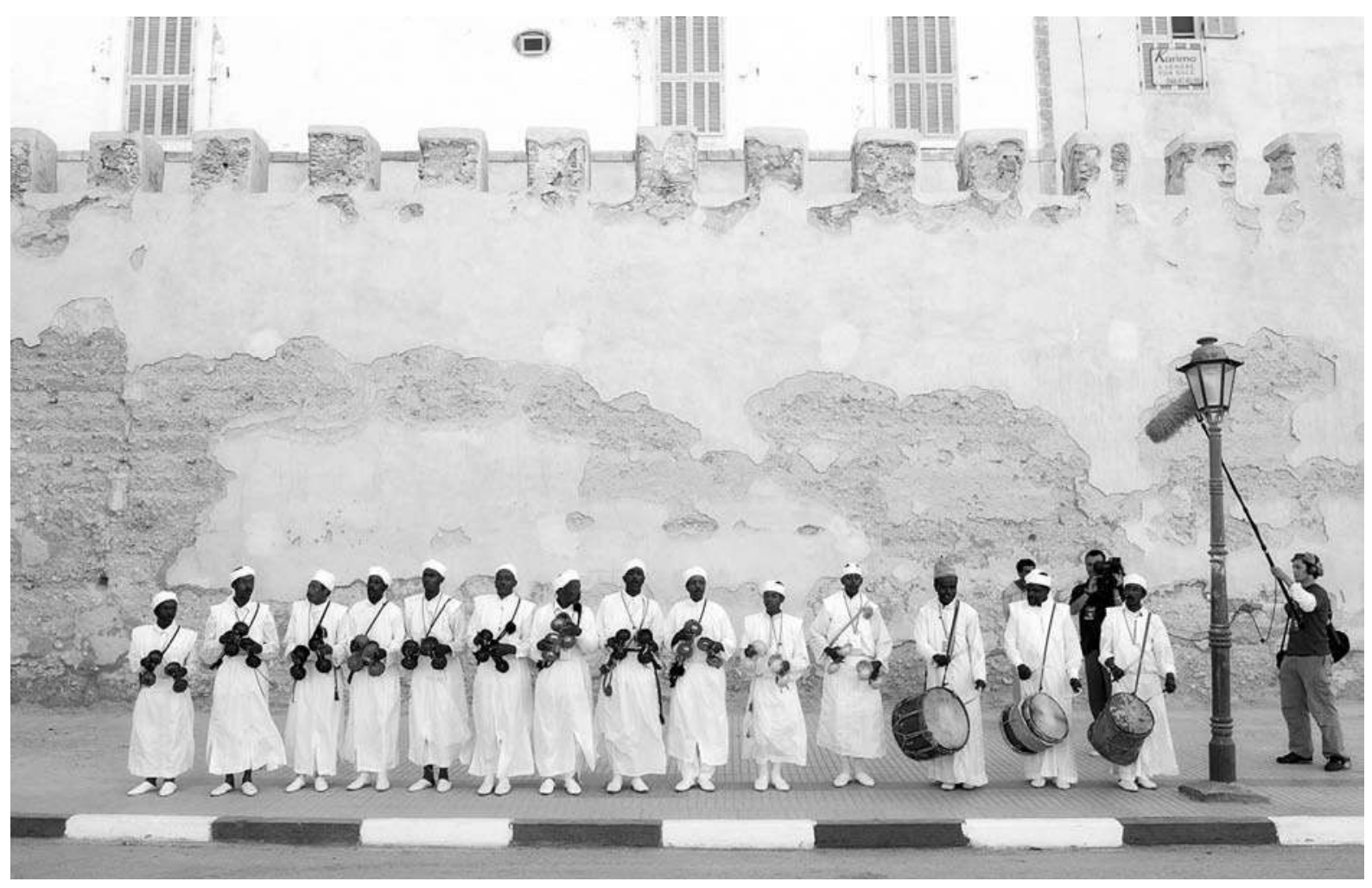

Fig. 6 Musiciens gnawa dans les rues d'Essaouira lors du festival, 26 juin 2003. @ P. E. R.

doesn't stop casting spells," ran one headline. 'The Essaouira Spirit' has become a cliché. Coined in English, it signals its popularity with and marketing toward American musicians and music-lovers. When I asked the current director, Neila Tazi, about what they were trying to create at the Gnawa festival, her reply was passionate and somewhat esoteric: "It's a very personal state. It's a space where one forgets everything. One is cut off from everything. That's the mystical side of it to create the void. It's hard to liberate the spirit. Here, they are seeking humanity, peace, harmony".

The brain-child of several professionals, including Moroccan ethnopsychiatrist and scholar of the Gnawa, Abdelhafid Chlyeh, as well as Neîla Tazi, Jane Lovelace, Abdessallam Alikane, and Pascal Amel, the festival began with only the music of the Gnawa and a few European artists that had collaborated with them. American composer and musician Richard Horowitz, for example, was the first artistic director and performed on stage in its early years, as did percussionist Adam Rudolph and saxophonist Archie Shepp. Now the festival boasts of Cheb Mami and Moroccan-American Gnawi Hassan Hakmoun, who, in 2004, played with an Indian tablaplayer and singer in his own version of Gnawa fusion. "When you have a conversation, each one has different ideas. That's how I like to see the music," explained Hakmoun when I asked him about the hybridity of his own music. Also on the 2004 stage were Cuban pianist Omar Sosa, Senegalese percussionist Doudou N'Diaye Rose as well as the Wailers, among whom Elan Attias, a Moroccan-born Jewish singer. All the religions of the book are represented.

In the first several years of the Gnawa festival, the ceremonies were performed in venues open to the public. The enactments included the public sacrifice of a sheep, as well as the burning of ritual incense to placate the spirits of the possessed. A lila (literally a "night" ceremony) was then held in several places in the city after the concerts in the public square, including the zawiya, or Gnawa sanctuary in the old city. Essaouira is one of the few cities in Morocco that has a sanctuary exclusively for Gnawa pilgrims.

Performing the ritual for festival-goers presented challenges and met with protest. To hold an "authentic" lila, some argued, it was necessary to propitiate the spirits with a blood sacrifice (usually a goat, a sheep or a chicken). Yet the ritual slaughter of a sheep was particularly criticized for making a display of a serious ritual and opening the Gnawa to criticism by those who understood little of the traditions. There are also 
beliefs that if the music that constitutes the core of the propitiation ceremony is played outside its ritual context, the spirits will get angry and enact retribution. Anthropologist Bertrand Hell notes that the Gnawa have even cultivated a reputation as charlatans and tricksters to deflect attention away from more serious aspects of their rituals and to thus preserve them (Hell 2002). In this scenario, the line between commercialism and mysticism is ambiguous, and the Gnawa play on this ambiguity fully, claiming both ritual secrecy and market mastery. After much discussion by the Gnawa masters and the festival organizers, the lila was transformed into what is called a fraja (a show, a spectacle) in Gnawa terminology, a term that distinguishes the sacred from the profane for Gnawa who perform for foreign audiences. Still billed as "lila," the shows no longer invoke the entire pantheon of spirits (each with their own color, music and incense). A public sacrifice is not enacted and the "lila" lasts only a few hours. The music, in other words, has been separated from its ritual function incrementally - at least as it is performed for foreigners and Moroccan tourists. In the process, a small scale ritual gave way to a much larger tourist production, eventually accommodating 400,000 audience members and necessitating the construction of several hotels and restaurants, including ones that cater to elites. (Indeed, I was invited to a "private" party held at one of the new five-star hotels, where elite, mostly Casablanci, tourists dined and drank Champagne as they circulated and displayed themselves by the pool). Despite the transition to a more cosmopolitan enactment, however, the ritual vocabulary is still employed at the festival and the ritual suites of songs (each dedicated to a different color or family of spirits), while not played to completion, are still the same ones used in the propitiation of the spirits. At the Gnawa Festival, the pains of transformation from local ritual to transnational spectacle are clearly evident. The lila (in the festival at least) has become a simulacrum of itself.

In the wake of the 2003 Casablanca bombings, security is extremely tight at these events. And although not as many people fall into possession trance behind a police barricade, it still does happen spontaneously. Despite the desacralization of the early years, trance is still the primary sign used to unite and promote the festival. All the international performers who come to

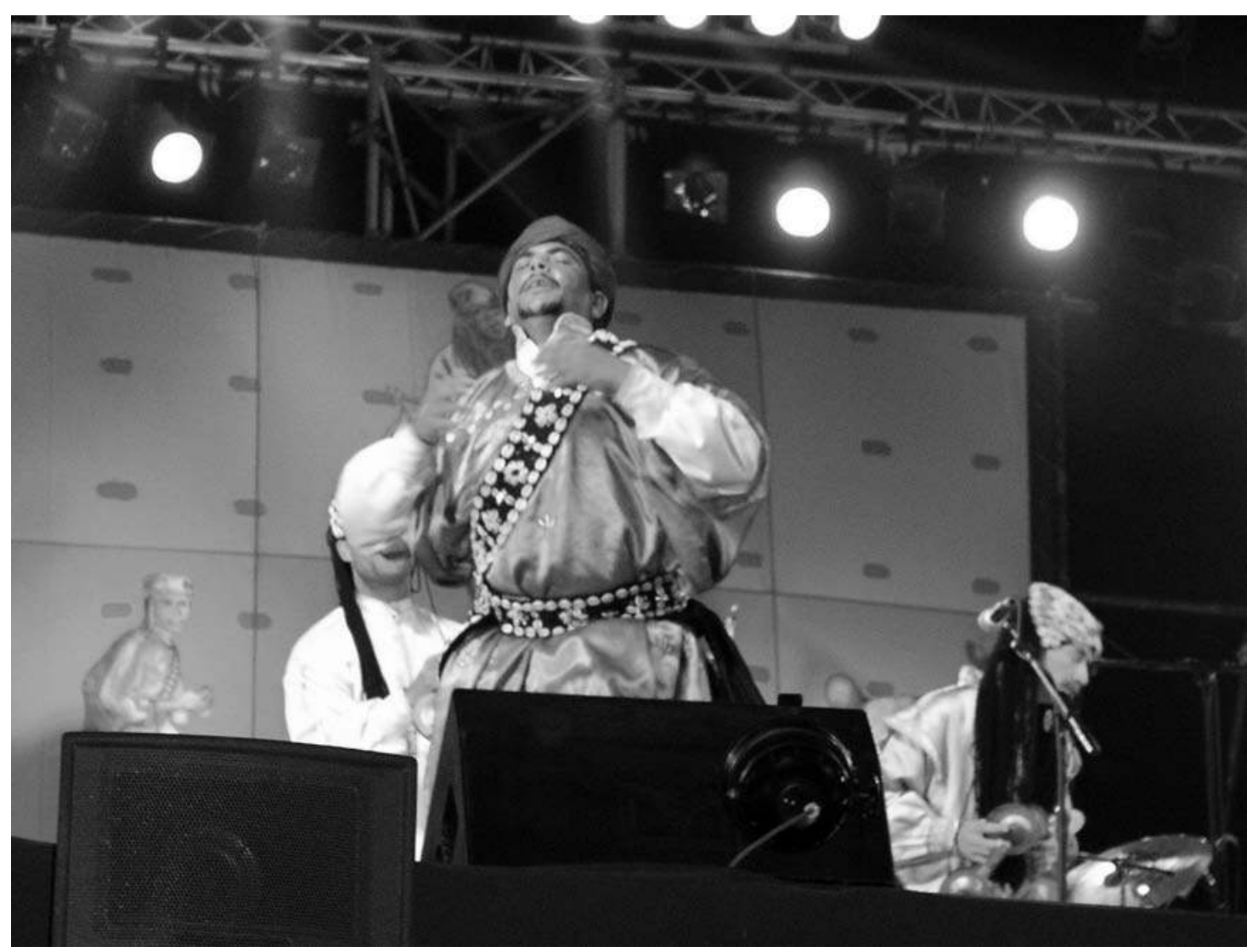

Fig. 7 Transe sur scène lors du festival, 2004. Photo Deborah Kapchan (D. K.). 


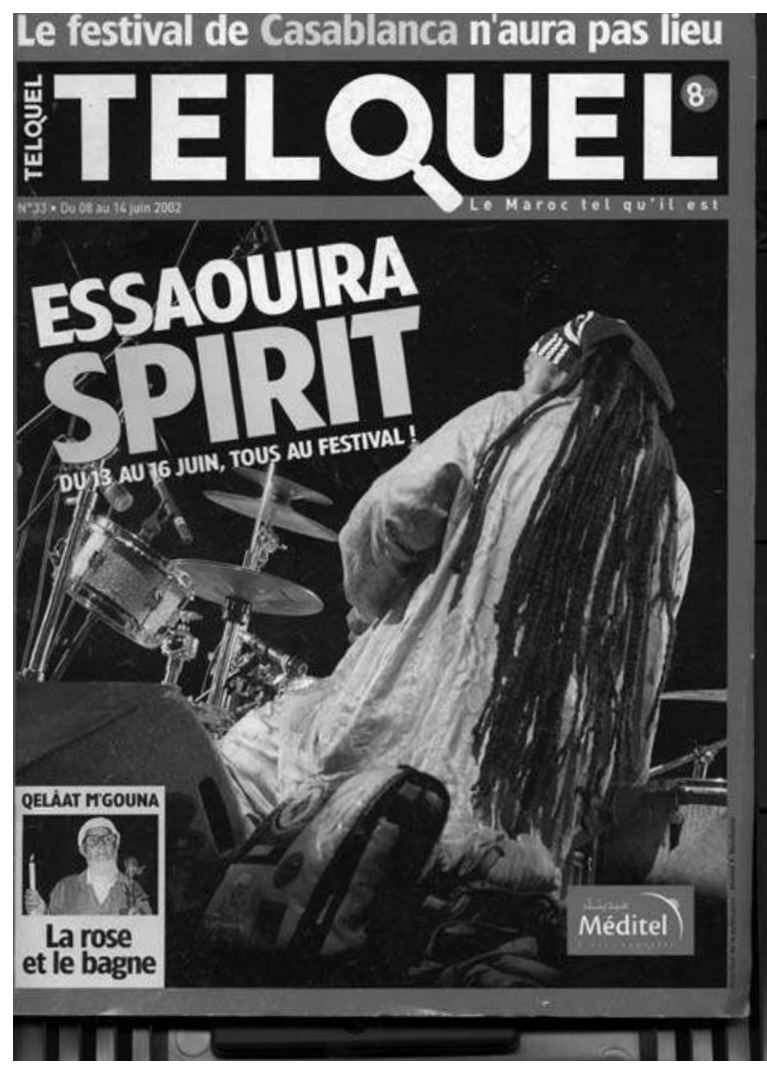

Fig. 8 Couverture du ${ }^{\circ} 33$ de la revue hebdomadaire Telquel, 2002. Photo D. K.

Essaouira play with the Gnawa - which means that the voices and characteristic cymbal rhythms of the Gnawa are heard in every tradition presented. Indeed, when the Gnawa enter, adding their African rhythms, the crowd goes wild. The gestural vocabulary of trance is in evidence everywhere (head slightly hung and swayed back and forth, arms by the side or behind the back, torso forward). Indeed, despite the natural and architectural lures of this quaint fishing port, the fetishization of trance is the primary modus operandus in attracting the hundreds of thousands who come each year to the festival (Kapchan 2007).

\section{The Essaouira Spirit and the Spirit of Place}

Essaouira is an historic city and, like the Fes festival, the Gnawa festival plays on the aura of place. "What is it that attracts people so different from each other, on opposite paths, and who come back regularly to taste the joys of Essaouira?" ask journalists Allali and Zizi (2002). "When asked the question, most of them speak of the atmosphere or ambiance belonging to the city, a sort of 'Essaouira Spirit.”

\section{What is the "Essaouira Spirit"?}

Like Fes, the site of the other most popular sacred music festival in Morocco, Essaouira has been a crossroads for travelers for centuries. This has had multiple ramifications. Essaouira was a Portuguese outpost in the 19th century and a former stop in the slave trade. It also had a large Jewish population before mass migrations to Israel after Moroccan independence. Indeed, in the 19th century, forty per cent of the population was Jewish (Shroeter 1988, 2002). At that time it was called the city of Mogador. As a repository of nostalgia by Moroccan Jews it has been the subject of documentaries and scholarly works and continues to be a tourist destination for Jews now living abroad. The presence of its mayor, André Azoulay, is also significant. A Jew, a financial expert, a counselor to the king, he represents many things, but particularly "cosmopolitanism." When I asked him how he felt about Essaouira being synonymous with the Gnawa, he was quick to tell me that the Gnawa Festival showcased some of the best jazz in the world: "The jazz that is here is as good as the jazz I've heard in New York or Chicago," he told me, without missing a beat. And, he was quick to point out, "We also have a festival of classical music here during the year." Despite the diversity of music performed in Essaouira throughout the year, however, the "Essaouira Spirit" is inextricably linked to the trance music of the Gnawa - and to the African aesthetic that permeates it.

The Gnawa Festival is also a festival in the strict definition of the term: it is carnivalesque. Fit four hundred thousand people into an old medina that has a radius of only a few miles and a carnival is produced - bodies overflowing into other bodies as the crowds surge down narrow streets toward the music, the smoke of grilled sardines at street stands hitting pedestrians in the face, the salty ocean wind blowing open scarves and sweaters and, once out in the open plazas, thousands upon thousands of people, young and not-so-young, thronging around the stage. The music in Essaouira is loud, sometimes uncomfortably so. Although a small area around the stage is barricaded and reserved for VIPs, even these sites have no or few chairs. The audience stands. They move. They dance. There are huge speakers that broadcast the music to the enthusiastic crowds. There are large screens that project images of the musicians to those too far from the stage to see them. The campsites are full, the cafés packed, the hotels booked. The Essaouira Gnawa Festival of World Music is a popular event - both in its appeal to the popular classes (espe- 


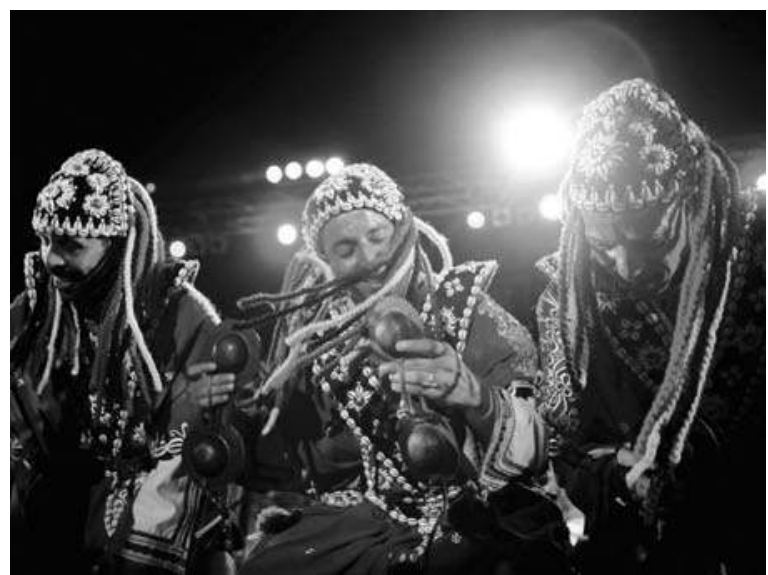

Fig. 9 Musiciens gnawa, 24 juin 2006. @ P. E. R.

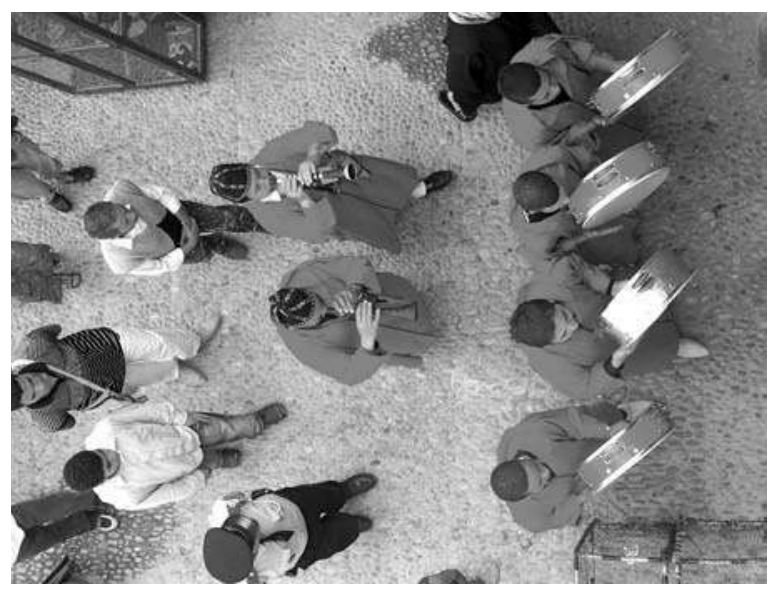

Fig. 11 Musiciens dans la rue, 27 juin 2003. @ P. E. R.

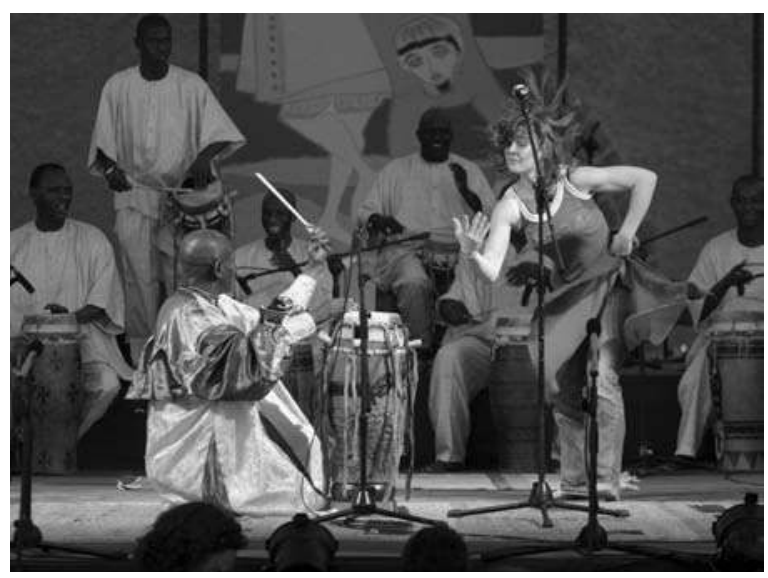

Fig. 13 Spectacle gnawa au festival, 24 juin 2004. @ P. E. R.

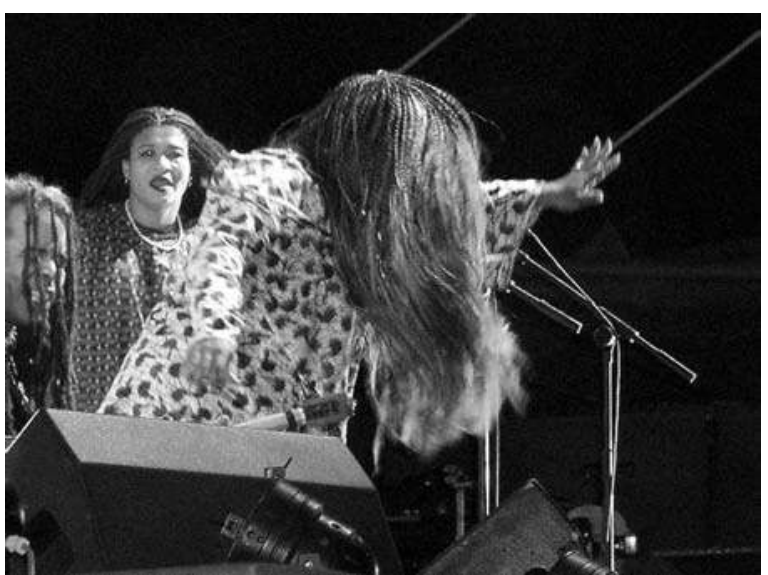

Fig. 10 Hassan Hakmoun et ses choristes, 2004. Photo D. K.

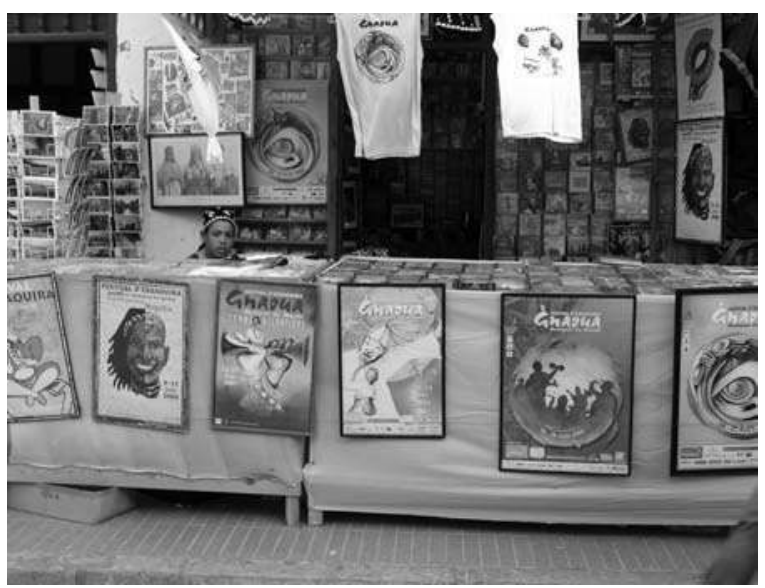

Fig. 12 Art gnawa à vendre, 2004. Photo D. K.

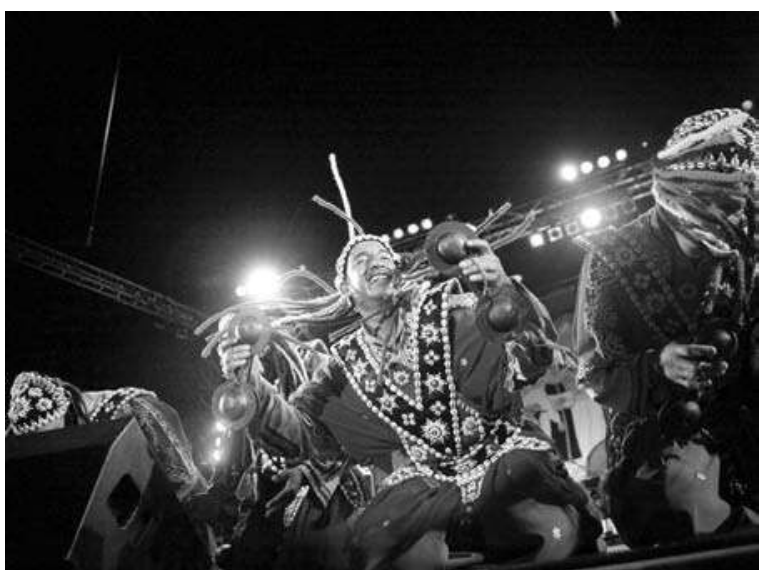

Fig. 14 Musiciens gnawa, 24 juin 2006 @ P. E. R. 


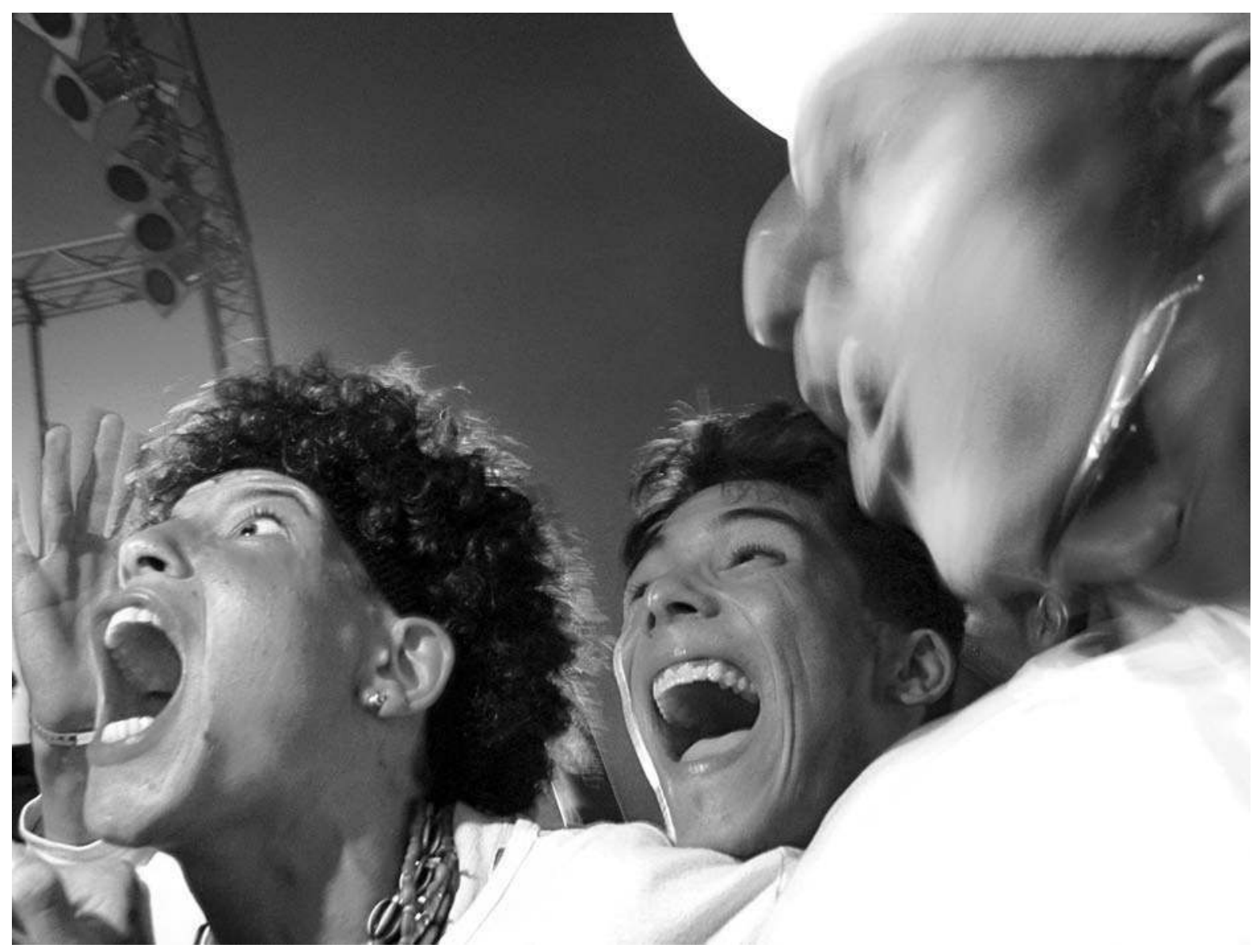

Fig. 15 Public du festival, 27 juin 2004. @ P. E. R.

cially youth) and in its popularity with Moroccans. It has become a pilgrimage center for Moroccan, European and American youth.

\section{The Fetish of Trance}

It is clear that the Essaouira Festival is also an important business venture. Within three years of the festival's debut, the city built several four and five-star hotels. Sofitel and other foreign-based companies invested here. Essaouira has been an artist colony for both Moroccans and foreigners since at least the 196os, but now new art galleries are springing up featuring "Gnawa art" - depictions of the instruments and ritual life of the Gnawa. Fetish items are created in response to the market for "ritual art." Indeed, an entire industry of material culture has grown up around the Gnawa - tee-shirts and hats with wool dredlocks to be sure, but also fine (and not so fine) art depicting the Gnawa musicians in trance, as well as their instruments. Dredlocks today, it should be mentioned, make reference to Jamaican culture, sym- bolizing Africa of course, but also drawing on the power of protest music and subaltern identity. Reggae has always been hugely popular among Moroccan youth. A cartoon in the 2003 edition of the magazine Exit: Urban Guide features the following conversation between two readers of the magazine: "The Wailers in Essaouira? Who are the Wailers?" asks one young man. "They are the Gnawa of Jamaica," answers his goateed friend.

A second Gnawa festival — the Festival of Gnawa Youth - has now sprung up, providing workshops in music and technology alongside concerts. In an article from the French-language journal L'Économiste, journalist Mohamed Ramdani notes that more than 120,000 people attended each of the four-night splinter festivals in 2006 and that the hotels were full (Ramdani 2006). He also noted that an agreement had been reached with a Spanish association and the "Essaouira Mogador Association" (the NGO of the Essaouira festival) to train young Moroccans to create a permanent audio-visual Internet stream. In other words, the festival is being used as a spring-board for development, both economic and social. 


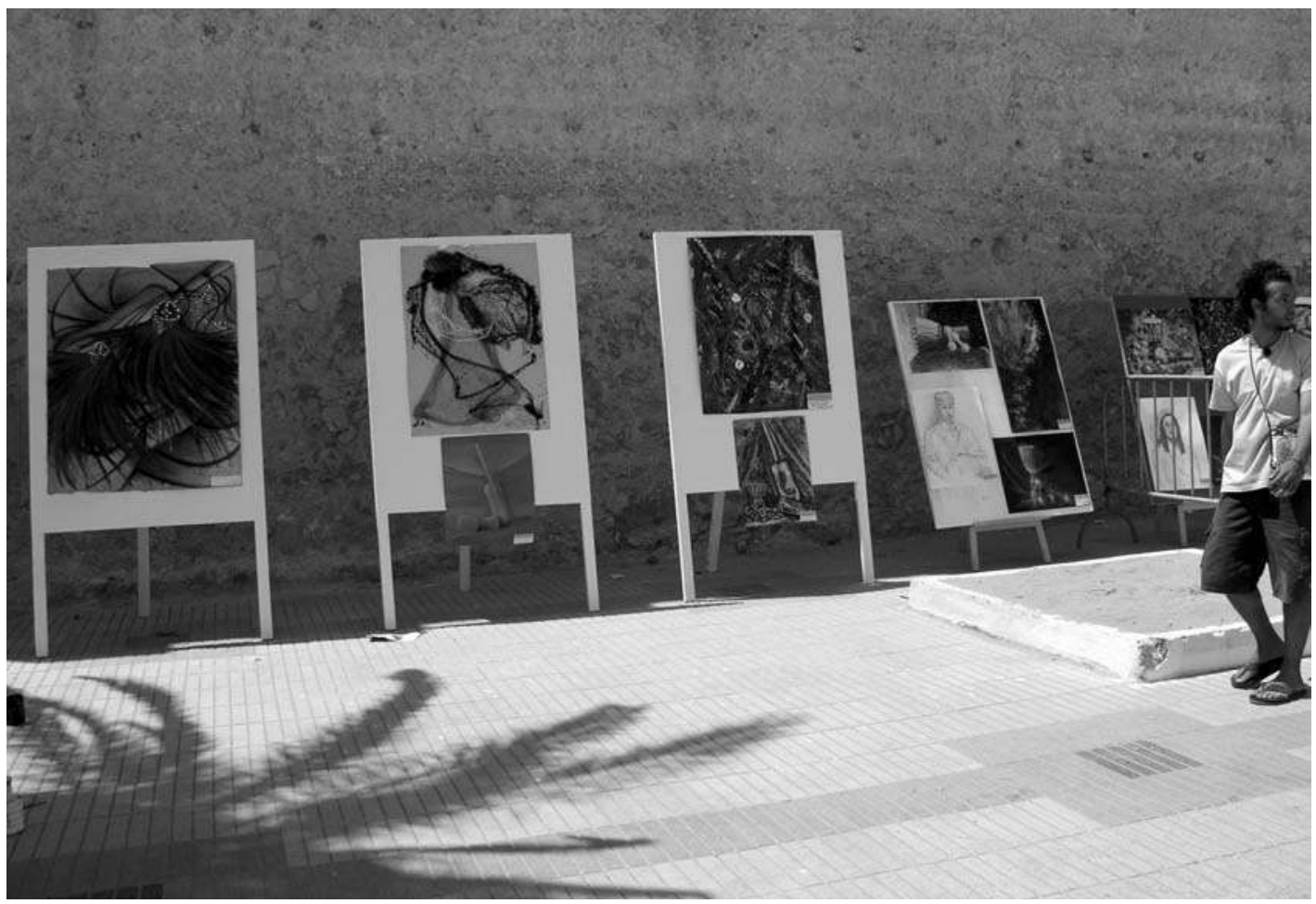

Fig. 16 Art gnawa, 2004. Photo D. K.

Icons of Sacred Identity

In Essaouira, African rhythms (particularly as they are represented by Gnawa music) come to stand for an identity that celebrates ethnic and religious differences as exemplified in the larger African diaspora. Inspired by African spirit pantheons, the "Essaouira spirit" gathers difference into itself, claiming — as do the Gnawa — that spirits may be legion, but there is ultimately "no God but God." The icon of identity here is rhythm. In most all of the collaborations with foreign artists whether American, European, African-American, or African - the Gnawa represent the rhythm section, while the guest artist does instrumentals or vocals. The Gnawa usually sing as well, although their signature contribution is the sound of the qraqab, the heavy metal castanets, that play one of two rhythms (both employing a triplet beat over a $4 / 4$ rhythm). As the guest artists join in with the Gnawa and their rhythms, they participate in a dialogue of styles. The Gnawa sound, like the Essaouira spirit, is iconic of Moroccan trance, and the collaborators do not imitate, but add to it, producing a hybrid mix: a world music aesthetic in which authentic Gnawa-ness (tagnawit) is recognized as a distinct and sacred voice. Much like the Moroccan multilingual who is able to understand elaborate code-switching from Arabic to French to Berber to English and back, the auditor for these hybrid musics has a trained ear that is able to identify the music's different stylistic components. World music has produced what I refer to as a "literacy of listening," an ability to hear the components in the mix (Kapchan in progress). Indeed it is this literacy that makes the promise of sonic translation possible in the first place. World beat has gone out into the world like a prophet preparing the way (Attali 1985).

It is no accident that these international festivals take place in a Muslim country at a time when all Muslim productions are being heavily scrutinized and analyzed by the West. Nor is it accidental that the 'moderate' and tolerant face of Sufism, as well as the larger African diaspora, is being used for political and capitalist ends. This festival creates both a national profile internationally and a transnational community in a Muslim locale. It also produces revenues for the State and for the city residents. There are times when the hopes of artists, intellectuals, NGOs, the State and international banks coincide. To the extent that the ritual knowledge base is lost, however (and it is hard to gauge the rapidity of this process), the promises veer in different directions. 
The Essaouira Gnawa Festival of World Music provides instructive models of how cultural and artistic production interweave with politics, economic development and religious discourse in the context of latecapitalism and tourism. A promise, after all, is an engagement. To be engaged is to be emotionally involved but also to be linked and implicated in relations of affective obligation (Kapchan 2006). The links created in these relationships produce the "Essaouira spirit" — an affective envelope that wraps communities in their hope. Inhabiting the promise of the festival, as well as the promise of sonic translation, audiences inhabit the hopes that the institution and its diverse and often divided constituencies create.

For Muslim countries that must counter the stereotypes as well as the realities of politicized Islam, religious identity may be cumbersome, carrying the weight of centuries of tradition, the weight of stereotypes in the media, being caught in the perpetuity of repeating stereotypes or refuting them (Abu-Lughod 1989). In this equation, the sacred is light. It travels in the voice, attaching itself to various sacred places, then lifting off again to land somewhere else. It is at home in the body; the rituals that the festival-goers experience function to anchor the promise of different sacred traditions in muscle memory. It is the experience, the "tasting" of these rituals that carries their impact. People travel thousands of miles to bath in the unique aura of a city, its smells and sights. From now on, they bear the mark of the pilgrim, someone who has sacrificed (time and money) to render homage to a promise - namely, the promise that the sacred exists in the connections between diverse people and not in the particular ideologies and aesthetics of their upbringing.
At the Gnawa festival, the translation of musical cultures finds it apogee in trance. The audiences at the Essaouira festival are brought together in a kind of creative and liberatory chaos, wherein the promise of sonic translation is experienced live, in a sacred place, with a community created of affective bonds. This place, these sounds, are then packaged and sold for export. Compact discs are bootlegged every year, and the festival-goers return to their place of origin with sounds that are supposed to link them to Essaouira as well as to each other. Audiences are brought back to the "sanctuary" through sonic memory, retaining the memory of their pilgrimage through an auditory token, a relic like the rosaries made of rose petals sold at the giftshops of European cathedrals. They also return with the material culture that is on display everywhere hats, tee-shirts, instruments, artwork, even dashiki. The sacred is, at least in part, a commodity created by the desire of those for whom it embodies use and exchange value. As a commodity, the festive sacred creates revenues for the tourist industry, symbolic capital for regional and national regimes, and a kind of spiritual capital for "pilgrims" who sacrifice their capital for the privilege of belonging to a community of affect created by the festival and its promise.

keywords / mots clés : Maroc // Maroc • Gnawa // Gnawa • trance // transe $\cdot$ festivals // festivals . Islam // Islam • music // musique religion // religion • tourism // tourisme • the sacred // sacré.

New York University deborahkapchan@mac.com 


\section{Bibliographie}

\section{ABRAHAMs, Roger D.}

1987 "An American Vocabulary of Celebration," in Time Out of Time: Essays on the Festival, Falassi, Alessandro (ed.). Albuquerque, University of New Mexico Press: 173-183.

\section{ABU-Lughod, Lila}

1989 "Zones of Theory in the Anthropology of the Arab World," Annual Review of Anthropology 18: 267-306.

\section{Alidali, Réda and Zizi, Yassine}

2002 “Essaouira Spirit," Telфuel 33, June 8-14: 1?.

APPADURAi, Arjun

2006 Fear of Small Numbers: An Essay on the Geography of Anger. Durham, Duke University Press.

\section{AtTALI, Jacques}

1985 Noise: The Political Economy of Music, translation by Brian Massumi, foreword by Fredric Jameson, afterword by Susan McClary. Minneapolis, University of Minnesota Press.

Austin, J.L.

1962 [1955] "How to do Things with Words," in William James Lectures. Cambridge, Harvard University Press.

BADONE, Ellen and RosEMAN, Sharon R. (eds.)

2004 Intersecting Journeys: The Anthropology of Pilgrimage and Tourism. Urbana, University of Illinois Press.

\section{BAKHTIn, Mikhail Mikhailovich}

1984 Rabelais and his World, translation by Hélène Iswolsky. Bloomington, Indiana University Press.

\section{BAUMAn, Richard, GAle CARPENTER} Inta and SAWIN, Patricia

1992 "Reflections on the Folklife Festival: An Ethnography of Participant Experience," in Special Publications of the Folklore Institute 2. Bloomington, Folklore Institute, Indiana University.

\section{BENJAMIN, Walter}

1969 "The Task of the Translator: An Introduction to the Translation of Baudelaire's Tableaux Parisiens," in Illuminations, Hannah Arendt (ed.), translation by Harry Zohn. New York, Schocken Books: 69-82.

Bohlman, Philip, V.

1997 "World Musics and World Religions: Whose World?," in Enchanting Powers: Music in the
World's Religions, Lawrence E. Sullivan (ed.). Cambridge, Harvard University Press: 219-235.

\section{BOURDIEU, Pierre}

1977 Outline of a Theory of Practice. Cambridge, Cambridge University Press.

BRANDES, Stanley H.

1988 Power and Persuasion: Fiestas and Social Control in Rural Mexico. Philadelphia, University of Pennsylvania Press.

\section{BRENNEIS, Donald}

1987 "Performing Passions: Aesthetics and Politics in an Occasionally Egalitarian Community," American Ethnologist 14(2), May: 236-250.

\section{CAiliois, Roger}

1960 Man and the Sacred [L'Homme et le Sacré], trad. Meyer Barash. Glencoe, Free Press of Glencoe.

\section{CHLYeH, Abdelhafid}

1999 Les Gnaouas du Maroc : Itinéraires Initiatiques Transe et Possession. Paris and Casablanca, Editions Le Fennec/La Pensée Sauvage.

\section{Chlyeh, Abdelhafid (ed.)}

2000 La Transe. Casablanca, Marsam.

\section{CORNELl, Vincent J.}

1998 Realm of the Saint. Austin, University of Texas Press.

\section{CRAPANZANO, Vincent}

1973 The Hamadsha: A Study in Moroccan Ethnopsychiatry. Berkeley, University of California Press.

2004 Imaginative Horizons: An Essay in Literary-Philosophical Anthropology. Chicago, University of Chicago Press.

\section{CSORDAS, Thomas J.}

1993 "Somatic Modes of Attention," Cultural Anthropology 8(2): 135-156.

\section{Delaney, Carol}

1990 "The 'Hajj': Sacred and Secular," American Ethnologist 1?(3), August: 513-530.

\section{Dermenghem, Émile}

1954 Le Culte des Saints dans I'Islam Maghrebin. Paris, Gallimard.

\section{DERRIDA, Jacques}

1985a "Roundtable on Translation", in The Ear of the Other: Otobiography, Transference, Translation, version angl. éditée par Christie V. McDonald, trad. Peggy Knauf. New York, Schocken Books. 1985b "Roundtable on Translation," in The Ear of the Other: Otobiography, Transference, translation by Christie V. McDonald (ed.) [based on the French edition by Claude Levesque and Christie V. McDonald, translation by Peggy Knauf]. New York, Schocken Books: 39-90.

\section{De VRIES, Hent}

2001 "In Media Res: Global Religion, Public Spheres, and the Task of Contemporary Comparative Religious Studies," in Religion and Media, Hent DeVries and Samuel Weber (eds.). Stanford, Stanford University Press: 3-41.

\section{Eickelman, Dale F.}

1976 Moroccan Islam: Tradition and Society in a Pilgrimage Center. Austin, University of Texas Press.

\section{EL HAMEL, Chouki}

2002 "'Race,' Slavery and Islam in the Maghribi Mediterranean Thought: The Question of the Haratin in Morocco," Journal of North African Studies 29(38).

\section{ENNAJI, Mohammed}

1992 Soldats, Domestiques, et Concubines : L'Esclavage au Maroc au XIx Siècle. Paris Balland.

\section{FaLASSI, Alessandro (ed.)}

1987 Time Out of Time: Essays on the Festival. Albuquerque, University of New Mexico Press.

\section{FeLD, Steven}

1994. "From Schizophonia to Schismogenesis," in Charles Keil and Steven Feld, Music Grooves. Chicago, University of Chicago Press.

\section{Fuson, Tim Abdellah}

2001 “'Where are you, Children of the Sudan?': The Recollection of Slavery in the lila Ritual of the Gnawa of Morocco," paper presented at the conference Slavery and Religion in the Modern Era. Essaouira, Morocco, June 15, 2001.

\section{Guss, David M.}

2000 The Festive State: Race, Ethnicity, and Nationalism as Cultural Performance. Los Angeles and Berkeley, University of California Press.

HAMmoudi, Abdellah

1997 Master and Disciple: The Cultural Foundations of Moroccan Authoritarianism. Chicago, University of Chicago Press. 


\section{HeLL, Bertrand}

1999 Possession et Chamanisme : Les Maîtres du Désordre. Paris, Flammarion.

2001 “'́Esclave et le Saint. Les Gnawa et la baraka de Moulay Abdallah Ben Hsein (Maroc)," in Saints, Sainteté et Martyre. La Fabrication de l'Exemplarité, Pierre Centlivres (ed.). Paris, Maison des Sciences de l'Homme: 149-174.

2002 Le Tourbillon des Génies : Au Maroc Avec les Gnawa. Paris, Flammarion.

\section{Kapchan, Deborah}

2006 "Talking Trash: Performing Home and AntiHome in Austin's Salsa Scene," American Ethnologist 33[3]: 361-37?.

2007 Traveling Spirit Masters: Moroccan Gnawa Trance and Music in the Global Marketplace. Music/Culture Series. Middletown, Wesleyan University Press.

\section{KeIL, Charles and FeLd, Steven}

2004 Music Grooves. Chicago, University of Chicago Press.

\section{KiRSHENBLATT-GimBLETT, Barbara}

1997 Destination Culture: Tourism, Museums, and Heritage. Berkeley, University of California Press.

\section{LYNCH, David}

2000 Staging the Sacred in Morocco: The Fès Festival of World Sacred Music, Master's Thesis, Anthropology. Austin, University of Texas.

\section{MacCannell, Dean}

1976 The Tourist: A New Theory of the Leisure Class. New York, Schocken Books.

\section{MaHMoud, Mamdani}

2002 "Good Muslim, Bad Muslim," American Anthropologist 104(3): 766-775.

\section{MAHMOOD, Saba}

2005 The Politics of Piety: the Islamic revival and the feminist subject. Princeton, Princeton University Press.

\section{Menocal, María Rosa}

2003 The Ornament of the World: How Muslims, Jews and Christians Created a Culture of Tolerance in Medieval Spain, foreword by Harold Bloom. New York, Little Brown.

\section{Meyer, Birgit and Moors, Annelies} (eds.)

2006 Religion, Media, and the Public Sphere. Bloomington, Indiana University Press.

\section{NoRA, Pierre}

1989 "Between Memory and History: Lieux de Mémoire," translation by Marc Roudebush, Representations 26: 12.

\section{Noyes, Dorothy}

2003 Fire in the Plaça: Catalan Festival Politics after Franco. Philadelphia, University of Pennsylvania Press.

\section{PÂOQUEs, Viviana}

1991 La Religion des Esclaves : Recherches sur la Confrérie Marocaine des Gnawa. BergamoRome, Moretti \& Vitalli Press.

\section{RAMDANI, Mohamed}

2006 "Essaouira: Le Festival des Jeunes Gnaoua Tient ses Promesses [Essaouira: The Festival of Gnawa Youth Fulfills its Promises]," L'Économiste, August 31st.

\section{ScHroeter, Daniel J.}

1988 Merchants of Essaouira: Urban Society and Imperialism in Southwestern Morocco, 1844-1886. New York, Cambridge University Press.

2002 The Sultan's Jew: Morocco and the Sephardi World. Stanford, Stanford University Press.

\section{SCHUYLER, Philip}

1981 "Music and Meaning among the Gnawa Religious Brotherhood of Morocco" The World of Music XXIII, $n^{\circ} 1$ : 3-10.

\section{TAYLOR, Timothy Dean}

1997 Global Pop: World Music, World Markets. New York, Routledge.

Tsing, Anna

2004 Friction: An Ethnography of Global Connection. Princeton, Princeton University Press.

\section{TURner, Victor (ed.)}

1982 Celebration: Studies in Festivity and Ritual. Washington, Smithsonian Institution Press.

\section{Résumé / Abstract}

Deborah Kapchan, The Festive Sacred and the Fetish of Trance. Performing the Sacred at the Essaouira Gnawa Festival of World Music. - What happens when a sacred and local practice such as trance is made into a fetish, detaching itself from its context of origin and circulating in transnational markets and international music festivals as a sign that carries its own power? When a ritual practice is so appropriated, it not only affects its performance context - the social milieu of its exchange - but the practice itself is transformed. This is the case with what is often called "trance" as it travels in the global market: it is made into a fetish, treated as an object with transformative powers, ultimately becoming a form of symbolic capital that helps create the category of the "sacred" in a transnational context. In this article I focus on one example of such fetishization - The Essaouira Gnawa Festival of World Music in Morocco. Emphasizing the "universality" of music, international music festivals like the one in Essaouira construct a notion of the sacred for audiences who come faithfully and perennially from great distances to "trance out" to the music.
Deborah Kapchan, Le sacré festif et la transe fétiche. La performance du sacré au festival gnaoua et musiques du monde d'Essaouira. - Que se passe-t-il lorsqu'une pratique sacrée locale telle que la transe est fétichisée, détachée de son contexte d'origine et mise en circulation en tant que signe autonome sur les marchés transnationaux et les festivals internationaux de musique? Lorsqu'une pratique rituelle est ainsi déplacée, cela n'affecte pas seulement le contexte de la performance - le milieu social d'échange - mais change également la pratique elle-même. Tel est le cas de ce que l'on nomme «la transe » lorsque qu'elle circule dans le monde globalisé : elle est fétichisée, traitée comme un objet doté de pouvoirs effectifs, elle devient finalement une forme du capital symbolique qui permet de recréer la catégorie du «sacré » dans un contexte transnational. Cet article se concentre sur un exemple d'un tel processus de fétichisation : le festival gnaoua et musiques du monde d'Essaouira au Maroc. En mettant l'accent sur «l'universalité » de la musique, les festivals internationaux de musique comme celui d'Essaouira construisent une notion de sacré pour des «fidèles » qui viennent régulièrement de loin afin d'être «emportés » par la transe musicale. 